\title{
Social Representation of Community Therapy in Patients of a Psychosocial Care Center in South Ceará
}

\author{
Sidney Medeiros de Oliveira ${ }^{1}$ \\ Lucimara Araújo Campos \\ Alexandre, \\ Francisco de Carvalho \\ Rodrigues $^{3}$; \\ Hidemburgo Gonçalves Rocha ${ }^{4}$
}

\begin{abstract}
The decentralization of health care in Brazil, which occurred in the last years since the 1988 constitution, has promoted changes in the mental health care sector. Some proposals for reform in the sector, such as the deactivation of psychiatric hospitals, were implemented. In place of the old asylums, new centers of mental health care emerged, with coexistence in open centers and use of multidisciplinary therapy. Today, the Psychosocial Care Centers called CAPS are already part of the reality of several cities in the country. In Ceará, there were several CAPS in the capital and the interior. In this context of changes also appeared a new therapeutic modality the Community Therapy - TC, implemented by professor Adalberto Barreto, first developed in Fortaleza in Quatro Varas Community, initiating a different approach of attention to mental health. In it the participants help themselves in overcoming their problems, improving their self-esteem and facilitating their return to social life. Our research was carried out with users of the CAPS in South Ceará area, aiming to study the influence of Community Therapy on the treatment of patients. The research was of qualitative character through interviews with users of the CAPS, participants of the Community Therapy. Conclusion: Community Therapy was perceived as positive, a contribution to emotional health. Socialization (environment of meeting with friends, a place of dialogue, where people are willing to listen, moment of fraternization) and a Ressignification (solution of a problem, development, a mental path, attitudes of sad people are softened) of the needs of its users.
\end{abstract}

Keywords: Community Therapy, Health, Mental Health.

\section{Introduction}

Since the XIX century that medicine established disease as its object of study. Their practices have thus been developed based on the physical location and classification of diseases from the patients, which over the years has been much discussed, mainly by Psychology, because it reduces the way of understanding about health, that is, only as absence of disease (Enumo, 2003).

\footnotetext{
${ }^{1}$ Faculty of Medicine of ABC, São Paulo, Brazil. meolli@ hotmail.com;

${ }^{2}$ Federal University of Vale do São Francisco, Pernambuco, Brazil. lucimara.univasf@gmail.com;

${ }^{3}$ Unissulivan Inc. franciscocrbio@hotmail.com.

${ }^{4}$ Federal University of Cariri, Ceará, Brazil. hibemburgo.rocha@ hotmail.com
} 
Canguilhem (1966/1990) argues that for common sense the concept of health distances itself from the scientific concept because, in this context, health is not only thought of as an absence of disease. Caponi (1997) believes that the concept of health is within the reach of all and goes beyond the limits of traditional medicine, because it is the result of a personal subjective experience, allowing to understand what happens with one's own body.

The concept of health proposed by the WHO as a state of complete physical, psychological, and social well-being has also been widely discussed by disregarding health as a process (Dejours, 1986, and Sarriera, Moreira, Rocha, Bonato, Duso \& Prikladnicki, 2003). Some authors mentioned the complexity that the health phenomenon assumed, especially in the last decades of the century. XX, which led to the expansion of the concept of health at the International Conference on Health Promotion in 1986, which began to consider several determinants, such as the type of food, the environment in which one lives, access to sanitation, social justice, work, income and education (Carvalho, 1996; Buss, 2000).

The interlocution with the Theory of Social Representations would add an emphasis in the field of health, when it proposes the patient's "way of knowing", thus contributing to the demystification of medical discourse (Trindade 1996, Enumo 2003). In this way, the healthdisease phenomenon is understood in a much broader way, including the social spaces delimited by the relations established in them, which are permeated by several factors ranging from the productive process, through religion, moral and ethical values, to the access to the official health structure, among others (Trindade, 1996).

The Social Representations Theory contributes significantly to this study when it reveals the patient's point of view about his illness. In this case, according to Trindade (1996), this "ceases to be a lean, poor and distorted conception of medical knowledge and appears as an autonomous way of thinking, with its own logic and coherence, whose analysis may be fundamental to the effectiveness of treatment and especially for the success of social health projects".

Knowledge of social representations may also be useful for planning preventive actions, since the beliefs and knowledge of those involved are fundamental to the success of preventive programs. 


\section{Method}

\section{Participants}

. There were interviewed 18 individuals, 04 men and 09 women, diagnosed with mental illness, undergoing treatment by CAPS (Center for Psychosocial Care) in a city in the south of the state of Ceará, all participants in Community Therapy implanted about two years ago this Center. Participants were available and had a favorable clinical condition during the period of data collection. The ease of access and contact with the professionals (doctors, nurses, psychologist and social worker) of this institution gave the opportunity to contact the participants, who were indicated by them.

The interviews were made during the Community Therapy meetings as a way to facilitate the interviews and to allow a broader view of the composition of the social representations of the new methodology adopted during their respective treatments.

All interviewees lived with the family of origin or with the family after the marriage.

\section{Data collection}

It was used a semi-structured interview script applied individually, covering the time of treatment with community therapy, treatment evolution, life changes, family / social coexistence, expectations, healing, and social representations of community therapy.

The issues addressed were elaborated based on our practice of attendance at the Center, as well as from works that described beliefs, fears and representations about health (Schulze, 1995; Neme \& Kato, 2003; Dóro et al., 2004).

According to Gaskell (2003), the semi-structured interview has been widely used in qualitative research because it is capable of providing the basic data for the development and understanding of the relations between individuals and their situation, since their objective is a understanding of beliefs, attitudes, values and motivations, in relation to behaviors in specific social contexts. 


\section{Data Collection Procedures}

Access and contact with the participants was granted by means of a written request sent to the direction of the CAPS.

There was no prior appointment of the interviewes, since we were directed to the place where the meetings took place, based on the indication of the health professionals (doctors, nursing, social work and psychology) and individually explained about the study and the possibility of granting the interview.

Participation of the interviewees occurred through free and informed consent, and a consent form containing a clear description of the data collection and confidentiality procedures was adopted, according to Resolution 510/2016 of the National Health Council (Ministry of Health and Oswaldo Cruz Foundation, 2016).

In addition, it was considered the emotional impact that the interview could cause to the participants, and in the case of detecting signs of emotional shock (crying, sadness, etc.) that could even compromise the general condition of the person, it would be referred to the Service of Psychology of the institution, which did not happen.

\section{Data Analysis}

The data of each interview were organized into "units of meaning" (aspects of the participants' reports that were considered important because they were closely related to the research objective) extracted from the interviews analysis (Trindade, 1991), below:

1) Representation of Community Therapy.

2) Perception of change after treatment;

3) Motivation that promotes participation in Community Therapy;

Reading these units showed that they could be discussed on the basis of a larger aspect around which the participants' psychological experiences were organized. This form of discussion of the results contributed to a better presentation and understanding of the same, and enabled the identification of possible variations in the elements of the social representations of Community Therapy. 


\section{Results and discussion}

Descriptions of the Category and Subcategories of the perceptions experienced by the subjects, in response to the question: "What is Community Therapy for you?"

With regard to Conception that the subjects had of the lived experience, in Community Therapy, only one category emerged: Positive.

Category 1: Positive - The experience was perceived as a contribution to emotional health. There were references to a set of positive feelings that were grouped into three subcategories:

\section{Subcategory 1 - Wellness:}

In this case, the experience was perceived as potentiating a state of physical and emotional comfort, when it evokes feelings of peace, love, happiness, from which a functional sense of well-being derives.

"peace"; "Love", "happiness", "lightness", "joy"; "quiet"; "great"; "a good thing"; "Many good things", "tranquility"; "Cheers"; "calm"; "Something very good", "peace"; "Provides great welfare"; "'It's very good"; "Provides relaxation";

\section{Subcategory 2 - Socialization:}

The experience was experienced as a tool that allows to broaden the relationships, creating a climate of greater intimacy and respect among the participants.

"A place of dialogue"; "Where people are willing to listen"; "A way of venting problems"; "Where there are people to hear it"; "Is distracted enough"; "Moment of fraternization"; expected all week "; "Distract the mind"; "Do not keep thinking nonsense at home"; "atmosphere of meeting with friends"; "Location of problems"; "Local council bases"; "An aid action"; "A support for their problems".

\section{Subcategory 3 - Resignification:}

In this case, the experience seems to have been the promoter of a new conscience about its self-confidence, when it evokes the possibility of solving the difficulties of the participants. 
"Problem solving"; "development"; "What helps us"; "Do not mess up"; "A mental path"; "For patient improvement"; "A victory"; "Attitudes of sad people are softened";

With regard to the Changes provided by Community Therapy, the reports denoted the following:

\section{A change of mental state:}

"More distracted and happy"; "Greater psychological security; "Calmer"; "Alleviation of problems"; "Search for a better way"; "Place to recharge the batteries"; "To become lighter"; "I improved the problem of the nerves"; "I stopped being empty thinking"; "I learned to occupy the mind."

\section{A change of attitude:}

"More obedient to parents"; "Improved relationships with others"; "I began to gain trust in others"; "Do not distrust everyone"; "I managed to live outside the residence"; "The right way to relate to other people."

Regarding the Main Reason to participate in the sessions of Community Therapy, the participants highlighted two categories:

\section{Category 1 - Improve Health:}

"carrying out parallel activities: painting, walks"; "Will to get well"; "Possibility of saving the life"; "Awareness of the need for treatment"; "Feel more at ease"; "Possibility of cure"; "Seek the cure to improve your health".

\section{Category 2 - Rehabilitation:}

"review the members of the CAPS"; "Leave the house to distract"; "Stop thinking bad things"; "People's readiness to listen"; "Search of people to talk"; "Attention to hear your problems"; "Interest in overcoming problems".

Considering social representations as processes through which close social objects are signified as interdependent, the social representation of Community Therapy could not be dissociated from well-being, socialization and a re-signification of contents that evoked a satisfactory resolution of their difficulties . 
Although all interviewees sought medical treatment as a means of curing mental illness, for some, healing depended also on the efficacy of Community Therapy, especially for those who demonstrated greater attachment to the new treatment.

According to Minayo (1994), situations of extreme suffering, of despair against illness among other problems, are motivating elements for the belief in the cure by unconventional means.

As noted, to participate in Community Therapy sessions, some participants begin to realize the importance of changing own attitude in their healing process, through recognition of own helplessness before the pain, suffering and / or the disease of the other participants, with which it begins to identify itself. We believe that the support and emotional comfort offered by Community Therapy can be one of the explanations for the strengthening of the affective bond with the group, providing a change of mental state, as reported by some participants.

The participation in Community Therapy produced a rupture in the participants' daily lives, which reported changes in their lives during this period, including changes in emotional state and changes in attitude in family, marital, loving and social relationships. Throughout the treatment, the search for more information about the common problems, together with the group and in the individual relationship with other people with the same difficulties, seems to have elucidated new parameters of reflection for the interviewees, who, from there, have passed to adopt new attitudes in their life of relationships and to themselves. This new way of living seems to have acquired a positive value for these people.

The majority of respondents attributed the same assessment to some of the changes reported, such as the valorization of the family and social life, as evidenced by the following statements: "more obedient to parents"; "Improved relationships with others"; "I began to gain trust in others"; "Do not distrust everyone"; "I managed to live outside the residence"; "The right way to relate to other people."

This is not to say that these changes have been experienced identically, but the shared meaning not only shows us how these changes are felt and evaluated, as it may indicate the existence of common elements characteristic of the process of being treated.

It is noticed, therefore, that other elements were incorporated into the social representation of Community Therapy from the moment the reason to participate in the sessions starts to play an important role in the treatment: Improve health and Resignation. The 
search for health seems to have promoted a return to more conscious condition of life. Facing more actively their difficulties in the treatment, the health happens to have a new meaning, like to feel that to be alive, present, being part of a social network, as reported in the following speeches of the participants: "accomplishment of parallel activities: painting, walks "; "Possibility of saving the life"; "Awareness of the need for treatment"; "Feel more at ease"; "Reviewing CAPS members"; "Leave the house to distract"; "Stop thinking bad things"; "search for people to talk"; "Interest in overcoming problems".

\section{Conclusion}

It was possible to highlight the importance of Community Therapy in the context of treatment, when it evoked in the participants a positive representation, related to Welfare, Socialization and Re-signification, allowing a new way of thinking about their social attitudes and practices.

The variations found in the elements of the social representations of Community Therapy show the possibility of health being manifested in a multiple way, not restricted to the absence of disease, incorporating other determinants such as socialization and resignification, which are important social values for the individual to recognize as subject.

We hope that these considerations may guide interventions in the field of mental health, not only of medical or psychology professionals, but also of other areas of knowledge that aim to promote health, so that it can also be valued as a right to which everyone should have access to.

\section{References}

Buss, P. M. (2000). Promoção da saúde e qualidade de vida. Ciência \& Saúde Coletiva, 5 (1), 163-177.

Canguilhem, G. (1966/1990). O normal e o patológico. Rio de Janeiro: Forense Universitária.

Caponi, S. (1997). Georges Canguilhem y el estatuto epistemológico del concepto de salud. História, Ciência, Saúde, 4 (2), 287-387. 
Carvalho, A. I. (1996). Da saúde pública às políticas saudáveis: Saúde e cidadania na pósmodernidade. Ciência \& Saúde Coletiva, 1 (1), 104-121.

Dejours, C. (1986). Por um novo conceito de saúde. Revista Brasileira de Saúde Ocupacional, 14 (54), 07-11.

Dóro, M. P.; Pasquini, R.; Medeiros, C. R.; Bitencourt, M. A. \& Moura, G. L. (2004). O câncer e sua representação simbólica. Psicologia: ciência e profissão, 24, (2),120-133.

Enumo, S. R. F. (2003). Pesquisas sobre Psicologia \& Saúde: uma proposta de análise. Em A. N. Andrade \& Z. A. Trindade (Orgs.) Psicologia e Saúde: Um campo em construção (pp. 1131). São Paulo: Casa do Psicólogo.

Gaskell, G. (2003). Entrevistas individuais e grupais. In M. W. Bauer \& G. Gaskell (Orgs.) Pesquisa qualitativa com texto, som e imagem (pp. 64-89). Petrópolis: Vozes.

Minayo, M. C. S. (1994) Representação da cura no catolicismo popular. Em P. C. Alves \& M. C. S. Minayo (Orgs.) Saúde e doença: um olhar antropológico (pp.57-71).Rio de Janeiro: Editora Fiocruz.

Ministério da Saúde - Fundação Oswaldo Cruz (2016). Diretrizes e normas regulamentadoras de pesquisas envolvendo seres humanos: Resolução 510/2016 do Conselho Nacional de Saúde. Rio de Janeiro: Fundação Oswaldo Cruz.

Neme, C. M. B. \& Kato, S. (2003). Mulheres com câncer de mama: Crenças sobre a doença e temores quanto ao tratamento. Em C. M. B. Neme \& O. M. P. R. Rodrigues (Orgs.) Psicologia da saúde: Perspectivas interdisciplinares (pp. 125-148). São Carlos: Rima.

Sarriera, J. C.; Moreira, M. C.; Rocha, K. B.; Bonato, T. N.; Duso, R. \& Prikladnicki, S. (2003). Paradigmas em psicologia: Compreensões acerca da saúde e dos estudos epidemiológicos. Psicologia e sociedade, 15 (2), 88-100.

Schulze, C. M. N. (1995). As representações sociais de pacientes portadores de câncer. Em M.J.P. Spink (Org.) O conhecimento no cotidiano: As representações sociais na perspectiva da psicologia social (pp. 266-279). São Paulo: Brasiliense.

Trindade, Z. A. (1991). Representações sociais da paternidade e da maternidade: Implicações no processo de aconselhamento genético. Tese de Doutorado. Instituto de Psicologia/USP, São Paulo/SP.

Trindade, Z. A. (1996). Representação social: "modo de conhecer" no cenário da saúde. Em C. Camino; Z. A. Trindade (Orgs.) Cognição social e juízo moral (pp. 45-59). Rio de Janeiro: Associação Nacional de Pesquisa e Pós-Graduação em Psicologia - ANPEPP. 
How to cite this article (APA):

Oliveira, Sidney M.; Alexandre, Lucimara A.C.; Rodrigues, Francisco de C.; Rocha, Hidemburgo G. (2017). Social Representation of Community Therapy in Patients of a Psychosocial Care Center in South Ceará. Am. In. Mult. J., Oct. 2 (3), 26-35.

Received: 5/6/2017.

Accepted: 9/20/2017. 